\title{
Pendampingan UMKM Batik Dalam Mengoptimalkan Nilai Tambah UMKM Melalui Pelatihan Pembuatan Motif Batik Khas Purbalingga
}

\author{
Christina Tri Setyorini ${ }^{1 *}$, Dewi Susilowati \\ ${ }^{1,2}$ Jurusan Akuntansi, Universitas Jenderal Soedirman, Purwokerto, Indonesia \\ *Penulis korespondensi, email: christina.setyorini@unsoed.ac.id
}

\begin{abstract}
Submit :
1 Des 2019

Diterima:

Abstrak. Kegiatan ini bertujuan untuk meningkatkan pemahaman dan keterampilan perajin batik mengenai motif batik khas

Terbit: Purbalingga. Adapun tujuan kegiatan ini adalah: meningkatnya

20 Des 2019 keterampilan peserta dalam melakukan desain motif batik khas Purbalingga, peserta mampu melakukan teknik desain yang baik dan berkurangnya ketergantungan kepada daerah lain dalam melakukan desain batik sehingga dapat menekan biaya produksi dan menekan harga jual. Objek dalam kegiatan Pengabdian Kepada Masyarakat ini merupakan ibu rumah tangga yang tertarik dan telah menekuni dunia perbatikan dari desa Metenggeng, Desa Cipaku dan Desa Sangkanayu Kecamatan Mrebet Kabupaten Purbalingga. Kegiatan dilaksanakan dengan memberikan penyuluhan dan pelatihan. Hasil kegiatan menunjukkan adanya peningkatan keterampilan desain batik dengan motif khas Purbalingga. Diharapkan peningkatan keterampilan membuat desain motif batik khas Purbalingga, dapat meningkatkan penghasilan perajin batik serta menjaga warisan leluhur.
\end{abstract}

Kata Kunci: batik, desain, keterampilan, motif, pelatihan 


\section{Pendahuluan}

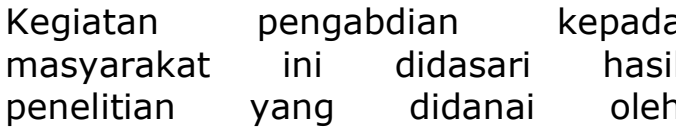
Direktorat Jenderal Pendidikan Tinggi (Dirjen Dikti) Kementerian Pendidikan dan Kebudayaan RI. Penelitian ini merupakan Prioritas Nasional Masterplan Percepatan dan Perluasan Pembangunan Ekonomi Indonesia (Penprinas MP3EI) yang dilaksanakan oleh tim pengusul pada tahun 2012, yang berjudul "Model Penguatan Usaha Mikro Kecil Menengah Klaster Batik di Jawa Tengah Selatan: Pendekatan Quadruple Helix" (Pinasti dkk, 2012). Penelitian tersebut melibatkan Disperindagkop dan UMKM batik 6 kabupaten di Jawa Tengah Selatan yang meliputi Kabupaten Banyumas, Purbalingga Banjarnegara, Wonosobo, Kebumen dan Cilacap. Usul kegiatan pengabdian ini hanya difokuskan pada Kabupaten Purbalingga dimana kabupaten ini yang pertamakali merespon hasil FGD (focus group discussion) yang diselenggarakan pada tanggal 26 September 2012 oleh tim pengusul dengan para pelaku usaha UMKM batik dan pihak Dinas Perindustrian, Perdagangan dan Koperasi (Dinperindagkop) dari 6 kabupaten di Jawa Tengah Selatan seperti tersebut di atas. Tidak kurang dari 70 orang hadir dalam pertemuan diskusi tersebut.

Berdasar hasil diskusi, meskipun keberadaan batik tulis khas Purbalingga belum semaju daerah yang lain, tetapi dinilai berpotensi untuk menembus pasar nasional maupun internasional. Apalagi keberadaan batik saat ini sudah diakui oleh UNESCO sebagai warisan budaya dunia. Sehingga untuk mencapainya, perajin batik tulis khas Purbalingga dituntut untuk terus memacu kreativitasnya agar tetap eksis. Terlebih lagi, pemerintah daerah menerbitkan peraturan daerah tentang penggunaan pakaian batik. Pegawai Negeri Sipil (PNS) di Purbalingga diwajibkan untuk memakai batik setiap hari Kamis dan Sabtu, sehimgga industri batik pun mulai tumbuh. Menurut data Dinas Perindustiran, Perdagangan dan Koperasi Purbalingga, hingga saat ini jumlah perajin batik terdiri dari perajin aktif sebanyak 273 orang dan 154 orang lainnya merupakan perajin yang tidak aktif karena lanjut usaia, bekerja di luar daerah, maupun yang telah beralih profesi), dan mayoritas ditekuni kaum wanita lanjut usia (diatas 50 tahun).

Namun demikian dari hasil surveimasih teridentifikasi beberapa masalah yang dihadapi perajin batik Purbalingga diantaranya adalah pada umumnya kerajinan batik dikerjakan secara tradisional (handmade) karena belum ada teknologi batik yang menggantikan proses manual(alat/mesin desain batik yang terkomputerisasi, tata letak produksi belum tersusun secara benar, hal ini memgurangi efisiensi waktu kerja. Menurut ibu Enmiyarti yang merupakan perajin batik dari desa Limbasari, sebagian perajin di desa Limbasari baru bisa mendesain dan membatik saja. Namun masih banyak perajin yang belum memahami ke khas an batik Purbalingga seperti motif lumbon dan jahe sarimpang. Pengenalan motif khas ini pada para pengrajin sangat baik untuk melestarikan warisan leluhur dan menjadi ciri khas daerah Purbalingga. Usul kegiatan ini memfokuskan pada pendampingan UMKM batik Purbalingga melalui pelatihan desain motif khas Purbalingga.

\subsection{Karakteristik UMKM di Indonesia}

Menurut UU No. 20 Tahun 2008 tentang Usaha Mikro, Kecil, dan Menengah dalam pasal 3 disebutkan bahwa Usaha Mikro, Kecil, dan Menengah bertujuan menumbuhkan dan mengembangkan usahanya dalam rangka membangun perekonomian nasional berdasarkan demokrasi ekonomi yang berkeadilan. 
Usaha Mikro Kecil dan Menengah (UMKM) di Indonesia menempati kedudukan strategis dalam peta pembangunan perekonomian Indonesia. UMKM di Indonesia merupakan basis dari perekonomian yang tumbuh dikalangan rakyat yang mempunyai potensi untuk ditingkatkan menjadi tulang punggung perekonomian negara. Oleh karena itu perlu disadari bahwa UMKM sangat potensial untuk ditingkatkan menjadi tulang punggung perekonomian negara apabila dilakukan perbaikan, peningkatan maupun penguatan terhadap komponen-komponen yang masih dianggap lemah (Noer Soetrisno, 2005). UMKM mempunyai peran penting dalam perekonomian, setidaknya 99,9\% dari seluruh kegiatan di Indonesia didominasi oleh UMKM sehingga UMKM mempunyai kontribusi yang besar terhadap penciptaan kesempatan kerja dan sumber pendapatan (Renstra Kementrian Koperasi dan UMKM, 2010).

Salah satu bidang UMKM yang banyak menyumbang penguatan lokal seperti menyerap tenaga kerja dan dapat bersaing global adalah Klaster Batik. Naiknya permintaan akan batik makin diperkuat dengan adanya deklarasi batik Indonesia sebagai warisan budaya dunia oleh UNESCO pada tanggal 2 Oktober 2009 lalu. Menurut Firmansyah, Indonesia merupakan negara yang memiliki peluang untuk dapat meningkatkan ekspornya setelah diberlakukannya ACFTA, yaitu dengan menyiasati produk-produk yang tidak mungkin disaingi oleh China seperti industri kain berbasis kreatif seperti halnya batik(Media Indonesia, 2012). Namun sayangnya masih banyak UMKM batik di Indonesia masih terkendala deng an biaya produksi tinggi karena masih harus melakukan sebagian proses produksi di luar daerah, akibatnya harga produk yang dihasilkan menjadi tinggi, sehingga sulit bersaing dengan produk batik dari daerah lain.

\subsection{Efisiensi Produksi} Meningkatkan Nilai Tambah UMKM Perbandingan biaya input dengan nilai output disebut dengan efisiensi produksi. Semakin kecil nilai efisiensi produksi, proses produksi akan semakin efisien. Sebaliknya, semakin besar nilai efisiensi produksi, proses produksi semakin tidak efisien. Efisiensi produksi akan meningkatkan nilai tambah perusahaan. Nilai tambah yang dimaksud adalah nilai tambah bruto yang diperoleh melalui mengurangi nilai output produksi dengan biaya input produksi (Badan Pusat Statistik, 2002). Nilai Tambah Bruto $($ NTB) = Nilai Output - Biaya Input. Nilai tambah (value added) adalah selisih penjualan dan biaya yang dikeluarkan untuk bahan baku dan pembelian material pendukung. Output adalah barang dan jasa yang dihasilkan dalam satu periode waktu tertentu.

Nilai output industri pengolahan didapatkan dari penjumlahan nilai barang yang dihasilkan dari sektor industri pengolahan, penerimaan bunga atas pinjaman uang yang diberikan kepada pihak lain, penerimaan atas sewa tanah milik perusahaan yang digunakan oleh pihak lain, penerimaan subsidi dari pemerintah dan pendapatan lainnya yang diperoleh dari kegiatan lain yang tidak dapat dipisahkan dari kegiatan industri pengolahan (Badan Pusat Statistik, 2002). Sedangkan definisi input atau biaya antara adalah pengeluaran biaya untuk barang yang tidak tahan lama dan jasa yang digunakan secara langsung dalam proses produksi dan pada prinsipnya umur pemakaiannya kurang dari satu tahun. Pengeluaran yang tidak termasuk dalam biaya input adalah sewa tanah, bunga modal, penyusutan barang modal tetap dan pajak tak langsung netto (Badan Pusat Statistik, 2002). 


\subsection{Potensi dan Hambatan yang dihadapi UMKM Batik di Indonesia}

Industri batik saat ini merupakan industry kecil dan menengah, dikombinasi dengan industri rumah tangga dengan keunikan/karakteristik bahan baku adalah kain (sutera, mori, katun, rayon, dan polyester yang berupa tekstil, Alat Tenun Bukan Mesin/ ATBM), malam (lilin), soda abu dan pewarna; tenaga kerjanya sebagian besar merupakan orang lain, meskipun ada beberapa yang melibatkan keluarga sendiri sebagai tenaga kerja aministratif dan bukan tenaga buruh; yang digunakan meliputi modal finansial dan modal fisik, sedangkan sebagian besar merupakan modal pribadi; dan proses pengolahan bahan mentah maupun barang setengah jadi menjadi barang jadi memiliki nilai tambah yang mempunyai ciri khas dan keunggulan tersendiri. Hasil dari industri batik dipasarkan baik untuk konsumen dalam negeri maupun diekspor keluar negeri seperti negara-negara Asia, Eropa, dan Amerika. Adanya perkembangan material dan teknologi, perkembangan batik dan produk batik menjadi sangat beragam, seperti batik tulis halus dan kasar, batik cap, sablon (screening) dan printing, kombinasi dari proses-proses tersebut dan keragaman produknya. Pola dan motif mengikuti dinamika konsumen baik nasional maupun internasional, sebagai batik dengan motif kontemporer. Terciptanya ragam hias batik etnis daerah yang mempunyai ciri khas dan keunikan masing-masing baik mengenai motif maupun tata warnanya maka batik dapat menjadi salah satu tambahan assets daerah dalam mengembangkan industri serta menyerap tenaga kerja. Namun selain potensi yang dimiliki, terdapat beberapa hambatan diantaranya adalah tingkat pendidikan dan pelatihan yang masih rendah, bahan baku yang mahal, modal yang terbatas, serta teknik pewarnaan yang belum dikuasai oleh perajin batik sehingga para perajin batik masih harus mengirim bahan setengah jadi untuk diwarnai juga dilorod (Pinasti et al., 2012 dan Setyorini et al, 2012).

\section{METODE}

Metode yang akan diakukan dalam kegiatan ini adalah:

\subsection{Pendekatan kepada calon mitra}

Yang sesuai, yaitu dengan menghubungkan mitra yang mempunyai keahlian dalam bidang desain kain dengan calon mitra yang membutuhkan keterampilan dalam pewarnaan kain. Pendekatan kepada mitra perajin batik di kabupaten Purbalingga Tim pengusul telah membangun hubungan baik dan komunikasi yang berkelanjutan dengan para tokoh perajin batik di kabuaten Purbalingga. Kesediaan untuk bekerjasama tampak jelas dari hasil komunikasi dan diskusi dengan para tokoh perajin batik tersebut.

\subsection{Mendiskusikan permasalahan dan solusi yang sesuai dengan kebutuhan mitra}

Diskusi terkait permasalahan UMKM batik Kabupaten Purbalingga telah dilakukan saat FGD tanggal 26 September 2012 dilakukan (Pinasti dkk, 2012). Berdasar FGD, dapat teridentifikasi permasalahan di UMKM batik Purbalingga diantaranya adalah masih rendahnya kemampuan perajin batik dalam desain batik. Hal ini juga dikuatkan kembali saat berdiskusi dengan ketua Forum Perajin batik Purbalingga, bapak Yoga Prabowo di sanggar batik Tirtamas yang menegaskan bahwa teknik desain batik masih belum dikuasai oleh para perajin sehingga mereka hanya mengerjakan pesanan dari pedagang besar berupa kain yang sudah disesain dan tingal melakukan pembatikan saja. Sehingga dari hasil perbincangan dapat disepakati bahwa pelaihan pewarnaan mutlak diperlukan agar para perajin mempunyai value added dan mampu menekan biaya produksi dan harga 
jual batik dapat bersaing dengan daerah lainnya.

\subsection{Menyepakati pelatihan sebagai metode yang tepat}

Berdasar kesepakatan dengan ketua Forum Perajin Batik Purbalingga, pelatihan pewarnaan menjadi suatu kebutuhan yang tidak bisa dihindarkan oleh perajin batik Purbalingga jika ingin dapat bersaing dengan daerah lain. Ketergantungan pewarnaan kain pada daerah lain menjadi tidak sehat bagi keberlangsungan usaha batik. Hal ini akan menyebabkan biaya produksi tinggi.

\subsection{Menentukan pelatihan}

prosedur

Berdasarkan hasil diskusi tim dan dengan mitra, disepakati bahwa pelatihan akan diberikan pada 20 orang pengrajin batik perwakilan dari sentra batik di kabupaten Purbalingga selama 3 hari, dimana dalam satu hari dibutuhkan waktu pelatihan selama 5 jam dan didistribusikan selama periode kegiatan. Peralatan dan zat warna untuk pelatihan telah disediakan oleh trainer yang difasilitasi oleh tim pengusul.

\subsection{Mendampingi kegiatan;}

Selama kegiatan berlangsung, tim pengusul mendampingi kedua mitra sehingga setiap kali muncul permasalahan, bisa segera dideteksi dan dicarikan solusinya.

\subsection{Rancangan Evaluasi}

Tujuan kegiatan ini ada 3 yaitu 1) meningkatnya keterampilan peserta dalam melakukan desain kain batik; 2)peserta mampu melakukan teknik desain yang baik; 3) berkurangnya ketergantungan kepada daerah lain dalam melakukan desain batik sehingga dapat menekan biaya produksi dan menekan harga jual.

Karena kondisi awal sudah diketahui, maka evaluasi hanya akan dilakukan di akhir kegiatan. Untuk mengetahui apakah keterampilan mewarnai para peserta pelatihan cukup memadai, akan dilakukan wawancara dengan para peserta dan observasi serta wawancara dengan pelatih. Untuk mengevaluasi tingkat pencapaian tujuan kedua, akan dilakukan wawancara dengan trainer desain batik yaitu bapak Yoga Prabowo, tujuan ketiga dievaluasi melalui wawancara dengan para peserta pelatihan.

\section{HASIL DAN PEMBAHASAN}

\subsection{Deskripsi Objek Pengabdian} Kepada Masyarakat

Objek dalam kegiatan Pengabdian Kepada Masyarakat ini merupakan ibu rumah tangga yang tertarik dan telah menekuni dunia perbatikan dari desa Metenggeng,Cipaku dan Sangkanayu yang terletak di Kecamatan Mrebet, Kabupaten Purbalingga. Deskripsi peserta pelatihan dapat dilihat pada Tabel 1.

Tabel 1. Deskripsi Peserta Pelatihan PKM

\begin{tabular}{lc}
\hline \multicolumn{1}{c}{ Keterangan } & Jumlah \\
\hline Usia $<20$ tahun & 0 \\
Usia $21-30$ tahun & 5 \\
Usia $31-40$ tahun & 12 \\
Usia $41-50$ tahun & 3 \\
Usia $>51$ tahun & 0 \\
Total & 20 \\
\hline
\end{tabular}

Sumber: daftar hadir pelatihan

Pada kegiatan Pengabdian Kepada Masyarakat ini selain diikuti oleh peserta pelatihan, dihadiri juga oleh perwakilan desa Metenggeng dan juga tim dari pihak mitra sebagai pelatih sebanyak 3 orang. Kegiatan pelatihan ini dibagi kedalam tiga jenis kegiatan yaitu tahap persiapan, tahap pelaksanaan dan tahap evaluasi.

\subsection{Tahap Persiapan}

Tahap persiapan dalam kegiatan pengabdian ini terbagi menjadi empat tahap, yaitu persiapan konsep pelatihan, ,persiapan peserta pelatihan, persiapan tempat, persiapan perlengkapan dan peralatan pewarnaan kain batik. 


\subsubsection{Tahap Persiapan Peserta}

Tahap persiapan peserta ini merupakan tahap dimana team pengabdian kepada masyarakat Unsoed melakukan koordinasi dengan mitra yaitu Bapak Yoga Prabowo selaku ketua FPBP untuk memastikan jumlah peserta pelatihan karena beliau mempunyai data pengrajin yang masih perlu dilatih dalam hal pewarnaan kain batik. Dari data yang diperoleh, jumlah peserta pelatihan terdiri dari 20 orang yang merupakan ibu rumah tangga dari desa Metenggeng, Desa Cipaku dan Desa Sangkanayu Kecamatan Mrebet Kabupaten Purbalingga.

\subsubsection{Tahap Persiapan Tempat}

Tahap persiapan tempat ini dilakukan dengan berkoordinasi dengan calon peserta pelatihan dimana Kepala Desa Metenggeng memberikan fasilitas di Rumah Warga Metengeng dengan menyediakan alat alat berupa kertas, pensil, untuk desain motif batik dan kompor, ember untuk mencelup dan media untuk penjemuran kain batik setelah dicelup.

\subsubsection{Tahap Persiapan Peralatan dan Perlengkapan}

Tahap persiapan peralatan dan perlengkapan merupakan tahap dimana team Pengabdian Kepada Masyarakat Unsoed berkoordinasi dengan mitra dari Forum Pengrajin Batik Purbalingga yang akan memberikan pelatihan mengenai kebutuhan akan perlengkapan, dan dengan pihak pengrajin batik desa mengenai kebutuhan akan peralatan. Dalam tahap ini disepakati bahwa peralatan yang ada yaitu kertas, pensil, kompor, penjemur kain dan ember disediakan oleh pengrajin batik sedangkan zat pewarna batik dann kain yang telah diberi motif (biron) akan disediakan oleh pelatih,untuk masing-masing 2 meter.

\subsection{Waktu Kegiatan}

Pengabdian masyarakat penerapan Ipteks dilaksanakan di Program pengabdian masyarakat ini berlangsung selama delapan bulan yang dimulai bulan April 2016 hingga bulan Nopember 2016. Adapun kegiatan pelatihan dilakukan di Desa Metenggeng, Cipaku dan Sangkanayu Kecamatan Mrebet, Kabupaten Purbalingga. Hasil yang diharapkan dari kegiatan ini adalah mampu meningkatkan pengetahuan terkait desain motif batik khas Purbalingga, pewarnaan kain, mampu meningkatkan daya saing dan dapat meningkatkan keberlangsungan usaha.

\subsection{Tahap Evaluasi}

Tujuan kegiatan ini ada 3 yaitu 1) meningkatnya keterampilan peserta dalam melakukan desain batik khas Purbalingga ; 2)peserta mampu melakukan teknik pewarnaan yang baik; 3) berkurangnya ketergantungan kepada daerah lain dalam melakukan pewarnaan kain sehingga dapat menekan biaya produksi dan menekan harga jual. Karena kondisi awal sudah diketahui, maka evaluasi hanya akan dilakukan di akhir kegiatan. Untuk mengetahui apakah keterampilan mewarnai para peserta pelatihan cukup memadai, akan dilakukan wawancara dengan para peserta dan observasi serta wawancara dengan pelatih. Untuk mengevaluasi tingkat pencapaian tujuan kedua, akan dilakukan wawancara dengan trainer pewarnaan yaitu bapak Yoga Prabowo, tujuan ketiga dievaluasi melalui wawancara dengan para peserta pelatihan.

Pada tahap akhir pelatihan, pelatih melakukan evaluasi terhadap kegiatan pelatihan menjahit ini. Hasil evaluasi pelatihan secara terperinci terlihat pada Tabel 2. 
Tabel 2. Evaluasi Peserta Pelatihan

\begin{tabular}{rll}
\hline No & \multicolumn{1}{c}{ Nama } & Kemajuan \\
\hline 1 & Siti Aminah & Baik \\
2 & Karilah & Cukup \\
3 & Priyati & Baik \\
4 & Racih & Baik \\
5 & Sumbinah & Baik \\
6 & Misti & Baik \\
7 & Rusyati & Cukup \\
8 & Iin Windarti & Cukup \\
9 & Toyibah & Baik \\
10 & Salma Labibah & Baik \\
11 & Sri Martati & Baik \\
12 & Pindah W & Cukup \\
13 & Endang Sri Budiati & Baik \\
14 & Kamsiyah & Baik \\
15 & Siti Saadiyah & Baik \\
16 & Sawinah & Baik \\
17 & Afif Yufilanita & Baik \\
18 & Suwarti & Baik \\
19 & Fadlun Edy Susilo & Baik \\
20 & Liris Kurniawati & Baik \\
\hline
\end{tabular}

Sumber: data primer yang diolah

Secara umum kegiatan pengabdian kepada masyarakat ini berjalan dengan lancar dan tidak mengalami kendala yang berarti apapun. Hal ini ditandai dengan respon dari peserta pelatihan sangat baik, dikarenakan semua peserta merasakan manfaat dari adanya pelatihan tersebut. Adapun respon dari peserta adalah sebagai berikut:

1. Peserta mendapat ketrampilan baru

2. Peserta mempunyai motivasi untuk dapat mengembangkan ketrampilan tersebut.

Adapun dari pihak mitra berpendapat, dengan pelatihan tersebut mendapat kesempatan mengembangkan usaha dengan bentuk kemitraan, dan menjadikan usaha sejenis berkembang di masyarakat.

\section{KESIMPULAN}

Seperti teridentifikasi dalam diskusi, masalah desain batik khas masih menjadi kendala bagi perajin batik, rata-rata hanya melakukan teknik membatik saja sedangkan desain batik masih sedikit pengrajin yang menguasai. Menurut Ketua Forum
Komunikasi Perajin Batik Purbalingga, Yoga Prabowo yang juga pemilik batik Tirtamas menyatakan bahwa perajin batik di Kabupaten Purbalingga secara umum belum bisa mendesain sendiri. Mereka hanya membatik dan mewarnai kain batik ke sentra batik di Sokaraja, Banyumas. Karena itu, untuk mengatasi permasalahan itu, Forum Komunikasi Perajin Batik Purbalingga yang dalam hal ini diketuai oleh bapak Yoga Prabowo telah melatih para perajin batik Purbalingga yang difasilitasi oleh tim pengusul dalam meningkatkan skill pewarnaan batik dan desain batik khas Purbalingga. Sehingga permasalahan desain batik akan dapat diurai dengan pelatihan desain batik, lebih lanjut dengan mengikuti pelatihan, maka perajin mendapatkan pengetahuan tambahan tentang desain batik secara mandiri, sehingga harapan kedepan perajin bisa mandiri dan dapat meningkatkan efisiensi biaya produksi yang pada akhirnya meningkatkan nilai tambah UMKM.

\section{Ucapan Terimakasih}

Terimakasih kepada LPPM Unsoed yang telah memfasilitasi pengabdian pada masyarakat ini. Terimakasih kami ucapkan kepada Bapak Yoga Prabowo yang telah memberikan pelatihan dan membantu dalam pelatihan mitra.

\section{DAFTAR PUSTAKA}

Badan Pusat Statistik ( 2002) Indikator Industri Kecil dan Kerajinan Rumahtangga. BPS, Jakarta

Kementrian Koperasi dan KUKM (2010). Rencana Strategis Kementrian Koperasi dan Usaha Kecil dan Menengah Republik Indonesia Tahun 2010-2014, Jakarta.

Kementrian Kordinator Bidang Perekonomian RI (2011). Masterplan Percepatan dan Perluasan Pembangunan Ekonomi Indonesia. Cetakan Pertama, Jakarta. 
Media Indonesia (2012). Produk UKM Indonesia bersaing dengan produk China. 5 April 2012

Pinasti, M., Setyorini, C.T, Rokhayati, H. 2012. Model Penguatan Usaha Mikro Kecil Menengah Klaster Batik di Jawa Tengah Selatan: Pendekatan Quadruple Helix. Laporan Hasil Penelitian MP3EI. LPPM Universitas Jenderal Soedirman.

Pinasti, M., Setyorini, C.T, Rokhayati, H. 2012. "Cooperative amongs SMEs and Coordinations among Government Institution in Indonesia: A Social Model to Strengthen The Internal Aspects of Batik Cluster in South-Central Java." Society of Interdiciplinary
Business Research (SIBR), 3rd, The Universiti Kuala Lumpur Business School (UBS).

Setyorini, C.T., Pinasti, M., Rokhayati, H. 2012. "Strengthening The Internal Factors of Batik Cluster SMEs in Indonesia: A Case of Six District in South-Central Java"Society of Interdiciplinary Business Research (SIBR), 3rd, The Universiti Kuala Lumpur Business School (UBS).

Soetrisno, Noer (2005). Ekonomi Rakyat Usaha Mikro dan UKM dalam Perekonomian Indonesia, Sumbangan untuk Analisis Struktural, STEKPI, Jakarta. 